\title{
Plant cell culture strategies for the production of natural products
}

\author{
Marisol Ochoa-Villarreal ${ }^{1}$, Susan Howat ${ }^{1}$, SunMi Hong ${ }^{2}$, Mi Ok Jang ${ }^{2}$, Young-Woo Jin ${ }^{2}$, Eun-Kyong Lee ${ }^{2} \mathcal{E}$ Gary J. Loake ${ }^{1, *}$ \\ ${ }^{1}$ Institute of Molecular Plant Sciences, School of Biological Sciences, University of Edinburgh, Edinburgh EH9 3BF, UK, ${ }^{2}$ Unhwa Corp., \\ Jeonju 55017, Korea
}

Plants have evolved a vast chemical cornucopia to support their sessile lifestyles. Man has exploited this natural resource since Neolithic times and currently plant-derived chemicals are exploited for a myriad of applications. However, plant sources of most high-value natural products (NPs) are not domesticated and therefore their production cannot be undertaken on an agricultural scale. Further, these plant species are often slow growing, their populations limiting, the concentration of the target molecule highly variable and routinely present at extremely low concentrations. Plant cell and organ culture constitutes a sustainable, controllable and environmentally friendly tool for the industrial production of plant NPs. Further, advances in cell line selection, biotransformation, product secretion, cell permeabilisation, extraction and scale-up, among others, are driving increases in plant NP yields. However, there remain significant obstacles to the commercial synthesis of high-value chemicals from these sources. The relatively recent isolation, culturing and characterisation of cambial meristematic cells (CMCs), provides an emerging platform to circumvent many of these potential difficulties. [BMB Reports 2016; 49(3): 149-158]

\section{INTRODUCTION}

Plants have evolved a vast chemical cornucopia driven primarily by the requirement to protect themselves from microbial pathogens, insect pests and grazing animals. To date approximately 200,000 NPs have been identified (1) and some of these have been utilised as drugs (codeine, morphine, paclitaxel) (2), food flavouring and colouring agents (saffron, spearmint and anthocyanins) $(3,4)$, pest and disease management chemicals (nicotine, strychnine and azadirachtin) $(5,6)$ and cos-

${ }^{*}$ Corresponding author. Tel: +44-131-650-5332; Fax: +44-131-6505392; E-mail: gloake@staffmail.ed.ac.uk

http://dx.doi.org/10.5483/BMBRep.2016.49.3.264

Received 22 December 2015

Keywords: Cambial meristematic cells, Hairy root culture, Natural products, Plant bioreactors, Plant cell culture metics and fragrance products (lavender, rosemary and Aloe vera) $(7,8)$. However, only a tiny fraction of this vast chemical space has been mined to date, therefore many blockbuster molecules await exploitation.

A variety of different methods have been developed to produce NPs, depending on molecular complexity, relative demand and the economics of production. A common strategy for obtaining NPs is extraction from the source plant but typically these plants have not been domesticated and their wild-populations maybe limiting. Additionally, the slow growth rate of the given source plant frequently reduces production potential. The typically low concentration of the active molecule in the source plant is also a potential brake on production.

The total chemical synthesis of NPs is an important alternative strategy. For molecules of relatively simple structure this provides an attractive route for production. Many NPs, however, have multiple chiral centres with region-specific and stereo-specific properties associated to their function (9), making total chemical synthesis either difficult or unprofitable. The production of NPs via semi-synthesis represents another approach that can circumvent some of the issues associated with the total synthesis of these high-value plant chemicals. This strategy is based on harvesting a more abundant chemical precursor integral to the biosynthetic pathway responsible for the generation of the target NP. For example, the production of the diterpenoid, paclitaxel (10). Semi-synthesis routes, however, still typically remain costly and often also generate toxic by-products, which can be damaging to the environment (9).

Plant cell culture (PCC) is a well-established technology platform for the synthesis of NPs. This approach provides several advantages in comparison to other potential strategies, especially for the production of NPs with complex structures. Significant progress has been made recently in plant cells platforms, building on the established expertise in microbial and animal cell culture. This has enabled the successful scale-up from experimental platforms to commercially feasible industrial scale processes. Thus, facilitating a series of high-value NPs to become commercially competitive in the market place, especially those of high-value (11).

The development of powerful new "omics" technologies, including next generation sequencing has provided exciting op- 
portunities for PCC. In this context, the number of patents related to PCC products has risen to a total of 28,000 and the amount of companies utilising PCC or hairy root technologies for the production of NPs associated with the cosmetic, food and pharmaceutical industries continues to rapidly expand (Table 1). Here we provide an update on the generation of NPs utilising PCC and highlight some of the strategies that can be undertaken to increase NP yields including: cell line selection, permeabilisation, biotransformation, scale-up strategies, immobilization, product secretion; and, the opportunities presented by the relatively recent isolation and culture of cambial meristematic cells (CMCs).

\section{PLANT CELL CULTURES}

PCC has become a well establish platform to produce plant

Table 1. Commercial production of natural products and heterologous proteins in plant suspension and hairy root culture. Modified from (15)

\begin{tabular}{|c|c|c|c|c|}
\hline Industry & Products & Species & Manufacturer & Use/Notes \\
\hline \multicolumn{5}{|c|}{ Plant Natural Products } \\
\hline \multirow[t]{8}{*}{ Food } & Anthocyanins & $\begin{array}{l}\text { Euphorbio milii } \\
\text { Aralia cordata }\end{array}$ & $\begin{array}{l}\text { Nippon Paint Co. Ltd, } \\
\text { Osaka Japan }\end{array}$ & $\begin{array}{l}\text { Textile dye } \\
\text { Coloring agents }\end{array}$ \\
\hline & Arbtin & Catharanthus roseus & $\begin{array}{l}\text { Mitsui Chemicals Inc., } \\
\text { Tokio Japan }\end{array}$ & Pigments \\
\hline & Betacyanin & Beta vulgaris & Nippon Shinyaku Co., Ltd & Pigments \\
\hline & Carthamin & Carthamus trinctorius & $\begin{array}{l}\text { Kibun Foods Inc., } \\
\text { Tokio Japan }\end{array}$ & Pigments \\
\hline & Geraniol & Geraminea spp. & Mitsui chemicals., Inc & Essential Oils \\
\hline & Gingseng & Panax gingseng & $\begin{array}{l}\text { Nitto Denko Corporation, } \\
\text { Osaka, Japan }\end{array}$ & Dietary supplements \\
\hline & & $\begin{array}{l}\text { Wild gingseng } \\
\text { from CMCs }\end{array}$ & $\begin{array}{l}\text { Unhwa Biotech Corp., } \\
\text { Jeonbuk, South Korea }\end{array}$ & $\begin{array}{l}\text { Dietary supplements, cosmetic and } \\
\text { medical products }\end{array}$ \\
\hline & Shikonin & $\begin{array}{l}\text { Lithospemum } \\
\text { erythrorhizon }\end{array}$ & Mitsui Chemicals., Inc & Red pigments \\
\hline \multirow[t]{7}{*}{ Pharmaceuticals } & Berberines & $\begin{array}{l}\text { Coptis japonica } \\
\text { Thalictrum minus }\end{array}$ & Mitsui Chemicals, Inc & $\begin{array}{l}\text { Anticancer } \\
\text { Antibiotic Anti-inflammatory }\end{array}$ \\
\hline & $\begin{array}{l}\text { Echinacea } \\
\text { polysaccharides }\end{array}$ & $\begin{array}{l}\text { Echinacea purpurea } \\
\text { Echinacea angustifolia }\end{array}$ & $\begin{array}{l}\text { Diversa, Ahrensburg, } \\
\text { Germany }\end{array}$ & $\begin{array}{l}\text { Immunostimulant } \\
\text { Anti-inflammatory }\end{array}$ \\
\hline & Paclitaxel & Taxus spp & $\begin{array}{l}\text { Phyton Biotech., Inc } \\
\text { Germany }\end{array}$ & $\begin{array}{l}\text { Anticancer World's largest cGMP } \\
\text { plant cell culture facility with } \\
\text { bioreactors specifically designed to } \\
\text { meet the needs of plant cell culture }\end{array}$ \\
\hline & & & $\begin{array}{l}\text { Samyang Genex., } \\
\text { Seoul, South Korea }\end{array}$ & Anticancer \\
\hline & Podophyllotoxin & Podophyllum spp. & Nippon Oil, Tokio, Japan & Anticancer \\
\hline & Rosamarinic acid & Coleus blumei & $\begin{array}{l}\text { ANattermann \& Cie. } \\
\text { Gmbh, Cologne, } \\
\text { Germany }\end{array}$ & Anti-inflammatory \\
\hline & Scopolamine & Duboisia spp. & $\begin{array}{l}\text { Sumitomo Chemical Co., } \\
\text { Ltd, Tokio, Japan }\end{array}$ & $\begin{array}{l}\text { Anticholinergicum } \\
\text { Antimuscrnic } \\
\text { Used in treatment of motion sickness, } \\
\text { nausea and intestinal cramping }\end{array}$ \\
\hline \multirow[t]{3}{*}{ Cosmetic } & $\begin{array}{l}\text { Atropine, Gingsenosides, } \\
\text { Coumarines, Flavonoids, } \\
\text { Alkaloids, Camptothechin, } \\
\text { Anabasine, Nicotine }\end{array}$ & $\begin{array}{l}\text { Hairy roots from } \\
\text { Atropa belladonna } \\
\text { Carlina acaulis } \\
\text { Nicotiana glauca } \\
\text { Panax gingsen }\end{array}$ & $\begin{array}{l}\text { Rootec, Witterswil, } \\
\text { Switzerland }\end{array}$ & $\begin{array}{l}\text { A wide range of products } \\
\text { for beauty health and nutrition }\end{array}$ \\
\hline & $\begin{array}{l}\text { About fifteen active } \\
\text { ingredients for } \\
\text { cosmetic use }\end{array}$ & $\begin{array}{l}\text { Cell suspension cultures } \\
\text { and hairy roots cultures, } \\
\text { different species }\end{array}$ & $\begin{array}{l}\text { Sederma, } \\
\text { Le Perray-en-Yvelines, } \\
\text { France }\end{array}$ & Develop of cosmetic active ingredients \\
\hline & $\begin{array}{l}\text { Active ingredients for } \\
\text { cosmetic use }\end{array}$ & $\begin{array}{l}\text { Suspension culture } \\
\text { and hairy roots } \\
\text { Malus domestica } \\
\text { Solar vitis }\end{array}$ & Mibelle, Switzerland & Develop of cosmetic active ingredients \\
\hline
\end{tabular}


Table 1. Continued

\begin{tabular}{|c|c|c|c|c|}
\hline Industry & Products & Species & Manufacturer & Use/Notes \\
\hline \multicolumn{5}{|c|}{ Heterologous proteins } \\
\hline & $\begin{array}{l}\text { Human Glucocerebrosidase } \\
\text { (GCD) enzyme }\end{array}$ & $\begin{array}{l}\text { Carrot suspension } \\
\text { cultures }\end{array}$ & $\begin{array}{l}\text { Protalix BioTherapeutics } \\
\text { Karmiel, Israel }\end{array}$ & $\begin{array}{l}\text { ELELYSO }^{\circledR} \text { Plant cell-expressed form } \\
\text { of the glucocerebrosidase enzyme } \\
\text { for treatment of Gaucher disease }\end{array}$ \\
\hline & $\begin{array}{l}\text { Vaccine against Newcastle } \\
\text { disease virus (NDV) }\end{array}$ & $\begin{array}{l}\text { Tobacco suspension } \\
\text { cultures }\end{array}$ & $\begin{array}{l}\text { Dow Agrosciences, LLC, } \\
\text { Indianapolis, USA }\end{array}$ & $\begin{array}{l}\text { First tobacco cell-based vaccine } \\
\text { approved by the FDA against } \\
\text { Newcastle disease virus in poultry }\end{array}$ \\
\hline & Human proteins & $\begin{array}{l}\text { Physcomitrella patens } \\
\text { suspension cultures }\end{array}$ & $\begin{array}{l}\text { Greenovation Biotech } \\
\text { BMBH Freiburg, } \\
\text { Germany }\end{array}$ & $\begin{array}{l}\alpha \text {-galactosidase for Fabry disease } \\
\text { and } \beta \text {-glucocerebrosidase } \\
\text { for Gaucher disease. } \\
\text { Both are in phase } 1 \text { of clinical trials }\end{array}$ \\
\hline & $\begin{array}{l}\text { Glycosylated recombinant } \\
\text { proteins }\end{array}$ & Hairy roots & $\begin{array}{l}\text { Root Lines } \\
\text { Amiens, France }\end{array}$ & Rhizo prot platform \\
\hline
\end{tabular}

NPs for the food, cosmetic and drug industries. In addition, this platform provides important tools to drive basic research. The production of valuable NPs using PCC has begun to garner significant attention due to its advantages relative to the production of NPs from natural harvest or semi-synthesis, from more abundant natural precursors (12). PCC provides a powerful production system for NPs independent from constraints resulting form geographical and seasonal variation and also limitations resulting from access to often dwindling wild plant populations. Thus, the PCC platform can aid the establishment of robust supply chains and help alleviate ecological problems and the loss of plant biodiversity (13-15). Importantly, the production of NPs from PCC is independent of food production. Further, the application of PCC technology reduces the requirement for precious water resources associated with contemporary agricultural production regimes. Commercialization of NPs produced via PCC have also gained significant consumer acceptance, since they are categorized as non-GMO $(16,11)$.

Plant cell suspension cultures offer the most reliable and productive system to generate NPs. An example of this is the production of geraniol, an important monoterpenoid for flavour and fragrance industries (17). While this NP was synthesized to slightly higher levels in transgenic tobacco plants, PCC proved to be overall the more commercially viable system when the simplicity in handling and the continuous nature of the process were taken into consideration. Thus, PCC was established as the ideal plant-based expression platform for the production of geraniol and related NPs (18). Furthermore, by utilising an appropriate culture medium and optimal levels of phytohormones, it is possible to establish in vitro cultures of most plant species. Following successful callus formation, cell suspension cultures can subsequently be generated, simply by adding these cells to a liquid medium. The resulting cultures typically have significant scale-up capability for their growth within industrially relevant bioreactors designed to maximize levels of NP biosynthesis.

\section{HAIRY ROOT CULTURES}

The cultivation of differentiated cells in organized tissues such as roots or shoots, constitutes an important alternative strategy for the production of high-value NPs (19). Hairy root culture are generated following infection with the gram-negative, soil bacterium Agrobacterium rhizogenes, which transfers a Transfer (T)-DNA from its large root-inducing (Ri) plasmid into the genome of the infected plant (20). The T-DNA carries a set of genes that encode for enzymes responsible for modulating auxin and cytokinin accumulation. The new hormone balance at the infection site mitotically activates surrounding cells inducing the formation of proliferating roots, so-called hairy roots. This phenotype is characterized by extensive branching, lack of geotropism and a high grow rate in the absence of exogenous hormones, $(20,21)$. Hairy root cultures are relatively easy to maintain and are genetically stable. Hairy root cultures have a successful track record in the production of a wide range of NPs including nicotine, ginsenosides, camptochecin, tropane and pyrrolizidine alkaloids (19, 20, 22). However, an important limitation in the production of NPs from hairy roots is that the target molecule must be synthesized within the roots of the given source plant. This is significant because relatively few NPs are synthetized in root tissues, with the majority produced in aerial structures. Further, another potential issue is that some root synthesized NPs are often translocated away from their site of production via either the phloem or xylem to distant sink tissues, where they are stored for chemical defence (22). Nevertheless, a number of NPs are both synthesized and accumulated in roots, including: scopolamine, atropine, anthraquinone, indole alkaloids cardiac glycosides (23).

Another major limitation for the industrial-scale production of NPs using hairy roots is the development of appropriate bio- 
reactor production platforms. Recent developments in bioprocess engineering have, nonetheless, driven the construction of bioreactors compatible with the industrial scale-up of hairy root systems. For example, ROOTec has developed a mistbased bioreactor for the production of a number of high-value NPs from a variety of plant species (http://www.rootec.com/) Table 1. In addition to NPs, hairy root cultures have gained attention for the production of pharmaceutical proteins due to their simple growth media requirements, genetic stability and capacity for scale-up (20). Thus, Root Lines Technology Inc. (http://www.rootlines-tech.com/) (Table 1) have exploited these properties for the industrial-scale production of recombinant glycosylated proteins.

\section{CELL LINE SELECTION FOR ENHANCED NP PRODUCTION}

Due to the heterogeneous population of typical dedifferentiated cells (DCCs) that comprise callus, the selection of a highly productive cell line has been an essential step for the establishment of profitable production platforms for NPs. As the accumulation of NPs in plants is genotype specific, the selection of suitable species and subsequently organs for callus generation is crucial (24). In addition, this selection process can be facilitated by elegant chemical-based approaches. For example, the identification of cell lines exhibiting a high level of metabolic flux through the targeted pathway by the exogenous application of an intermediate. Thus, cell lines with enhanced biosynthesis of rosmarinic acid in Lavandula vera were obtained by adding two different analogues of phenylalanine ( $m$ - and $p-F-D, L$ phenylalanine), the substrate of phenylalanine ammonia-lyase (PAL), to the medium. Only cell lines with high levels of PAL activity were resistant to the analogue, reflecting their ability to produce elevated levels of the target $\mathrm{NP}$, rosmarinic acid (25). In a similar fashion, high producing shoots of Mentha arvenis were screened by the addition of menthol into the medium. The selected clones exhibiting high menthol tolerance identified genotypes with superior performance for the production of increased quantities of menthol, for possible large scale production (26).

A major limitation following the selection of a suitable cell line for NP production is that cell lines often loose their ability to produce the desired NP $(15,19,27)$. This decrease or complete loss of NP biosynthesis is thought to be due to genetic instability resulting from somaclonal variation. This chromosomal rearrangement that occurs during long-term subculture, has been associated with aneuploidy and polyploidy. The resulting genetic variation affects chromosome structure causing genetic modifications including deletions and insertions that may affect the production of NPs (28). Subpopulations of cells with different DNA contents due to a change in ploidy were found in Taxus media cells after 1 year of subculture (29). Further, differences in ploidy are related to changes in gene expression, in general higher ploidy appears to result in the si- lencing of an increased number of genes (28). Changes in culture performance resulting from these deleterious genetic changes typically necessitates periodic screening in order to maintain the desirable characteristics of the given culture system (29). In this context, the application of a selectable marker within plant cells under culture, combined with flow sorting techniques, has been utilised to circumvent this problem, maintaining high performing cells for more than 12 months (30).

\section{CULTURE CONDITION OPTIMIZATION}

Following selection of high performing cell lines, another key consideration is to establish optimum media and culture composition. Optimization of growth, maintenance and production media are necessary to achieve high NP production. Although standard PCC medium such as MS (31), SH (32), Gamborg B5 (33) and LS (34) provide a platform for the growth and maintenance of plant cell lines, enhanced production of NPs can be manipulated by further media modification. Significant benefits can be gained by identifying the optimum culture medium environments early in the production timeline, addressing the integrity and stability of the specific NP to be produced. Some of the most useful modification made in the growth medium to promote NP production are related to the source of energy, nitrogen, phosphate, growth regulators, and inoculum density (24).

In general plant cell growth and the production of NPs are inversely related. Thus, production of NPs typically occurs in late stationary phase and is associated with growth inhibition and the production of enzymes for secondary metabolism. Therefore, a dual system to produce NPs is particularly effective, in which the first phase is for cell growth, followed by cell transfer to production medium, which does not support growth, but is favorable for NP biosynthesis (35). Typical modifications to the production medium include the reduction or elimination of phytohormones such as 2,4-D; reduction in phosphate levels; an increase in sucrose levels or modification of the carbohydrate:nitrogen ratio (35).

Screening of high producing genotypes, selection of adequate medium, and optimization of the culture environment for PCC may increase production of NPs by 20-30-fold (19). However, the optimization of plant-based production systems is a relatively nascent area. In this context, promising new strategies are emerging that hold significant promise for future application. For example, the use of a non-invasive, in-line system to monitor cell biomass during culture can be an important step to maximize product yield and quality, while improving culture nutrients (36). Also, culture parameters including levels of phytohormones and components within the media can be optimized more rapidly by employing a statistical design of experiments approach (37). This strategy has been shown to be successful for the optimization of culture parameters for M12 antibody production in hairy root cultures 
(Häkkinen et al., 2014) and in the production of a human antibody in a BY-2 tobacco cell suspension culture (37). The same strategy has also been used to promote biomass accumulation and geraniol production in tobacco cell suspension cultures (39). Therefore, experimental design strategies, in combination with in-line monitoring, maybe greatly beneficial during the early steps in screening and optimization for the establishment of high producing cell lines.

\section{ELICITATION}

The biosynthesis of NPs is integral to plant immune responses activated in response to attempted pathogens ingress or exposure to a range of abiotic stresses (40). Therefore, so-called elicitors, derived from pathogen associated, plant immune-related or stress signalling molecules, can trigger immune or stress-related NP production. A diverse range of biotic elicitors have been utilized including plant cell wall fragments (pectin and cellulose) and polysaccharides from microorganism (chitin and glucan) (41, 42), plant immune signalling molecules (salicylic acid and methyl-jasmonate (MeJA) $(43,44)$. Abiotic elicitors include: inorganic salts, heavy metals, UV irradiation, high salinity and high pressure (45). The application of the immune-related MeJA has been particularly widely utilized. For example, addition of MeJA to Taxus cuspidata CMCs induced the production of the blockbuster anticancer drug, paclitaxel, $14,000 \%$ in comparison with mock-treated cells (46).

Elicitor concentration, cell age and the stage of the given culture at the moment of elicitation are all important factors necessary to optimize the production of NPs (24). Thus, a significantly higher production of paclitaxel was obtained when MeJA was added to an 8 day-old culture in comparison to a 14 day-old culture (44). The addition of a combination of elicitors is another common practice in PCC with the advantage not only in increasing the production of a given NP but also often its release into the medium. The employment of MeJA in combination with cyclodextrin led to a synergistic effect on resveratrol production in grapevine cell cultures (47). A synergistic effect was also found on paclitaxel accumulation in T. media cells using MeJA and cyclodextrins. Both elicitors induced taxanes and advantageously, paclitaxel was detected mainly in the culture medium. Interestingly, this correlated with elevated expression levels of genes encoding $\mathrm{ABC}$ transporters. Therefore, if this process could be successfully scaled-up, purification costs for paclitaxel could be significantly reduced (48).

\section{IMMOBILIZATION OF PLANT CELLS}

Immobilization techniques were initially developed to immobilize enzymes for applications in the industrial production of sugars, amino acids and pharmaceutical products (49). Subsequently, immobilization was utilized to enclose cells. The advantages of this technique are that it provides high cell concentrations for use in small bioreactors, protection from shear stress for cell lines with high sensitivity and increases product formation by enabling maintenance of biomass over a prolonged period (24). Given that most NPs are produced in the stationary phase of growing cells, immobilization potentially could create an excellent environment for the production and accumulation of plant NPs. The most common immobilization agent is calcium alginate which has been deployed in the production of paclitaxel (50), vanillin, ajmalicine and capsaicin (51). However, there are no currently registered companies that utilize plant cell immobilization as a platform to produce NPs. Immobilization has been employed for the commercial production of pharmaceutical proteins where cell encapsulation in alginate increased the production of human granulocyte-macrophage colony-stimulating factor (GM-CSF) in tobacco cells by $\sim 50 \%$ (52). Thus, the application of immobilized plant cells may constitute a significant opportunity to enhance the future industrial production of NPs. Nevertheless, limitations associated with nutrient and metabolite mass transfer remain a challenge to be addressed before the implementation of immobilized plant cells at commercial level for NP production can commence.

\section{PERMEABILISATION, SECRETION AND EXTRACTION OF NPs}

Permeabilisation aids the release of given products without affecting cell viability and the biosynthesis capacity of cell cultures. Cell permeabilisation facilitates the removal of NPs from vacuoles and membrane systems of the plant cell facilitating the secretion of products into the culture medium, simplifying purification procedures (51). Different permeabilising agents have been used to facilitate the release of the product stored, including the organic solvents isopropanol and dimethylsulfoxide (DMSO) and also chitosan (53). The concentration and time of addition of the permeabilising agent to the medium are key parameters to avoid cell growth inhibition. In the case of Taxus chinensis cell cultures the addition of a low concentration of hexadecane, decanol and dibutylphthalate contributed to the release of paclitaxel into the medium (54).

The accumulation of NPs can be affected by enzymatic or non-enzymatic degradation of the NP in the medium (51) and/or by feedback inhibition of product synthesis (54). The application of in situ product removal, aims to prevent any subsequent cross interference between the product and the producing cell (55). In situ product removal involves direct separation of the product from the culture medium while its production is progressing and may be undertaken either by liquid-solid (in situ adsorption) or liquid-liquid (in situ extraction) systems (56). These processes can aid product recovery, increasing culture productivity and mitigating toxicity caused by waste materials released from cells, significantly decreasing the cost of downstream processing. Solid-liquid systems such as activated charcoal, XAD-4 and XAD-7 resins typically enable better outcomes compared with liquid-liquid systems. 
Activated charcoal has been used to increase the production of vanilla and coniferyl aldehyde. XAD-4 has been successful employed for chlorogenic acid, caffeine, paclitaxel and vanilla. While XAD-7, has improved the production of anthraquinonces, ajmalicine, serpentine, plumbagin and paclitaxel (56).

\section{BIOTRANSFORMATION}

Biotransformation is another strategy that can be used to produce high-value-chemical products in plant cells or organ tissues $(24,57)$. Biotransformation involves the chemical conversion of supplied substances catalyzed by biological systems, plant cells organ tissues or enzymes $(58,59)$. This strategy has the advantage of transforming inexpensive, available and plentiful products into rare, expensive and high-value NPs. The method is based on exploiting enzyme reactions including: hydroxylations, glycosylations, oxidoreduction, hydrogenation, hydrolysis, methylations, acetylation, isomerizations and esterifications $(59,60)$.

Previously, the application of biotransformation was limited by the absence of knowledge related to plant secondary metabolism (59). However, the recent advances in "omics" technologies have enabled significant advances in our understanding of plant secondary metabolism. Hairy root cultures, due to their genetic and biochemical stability, plant hormone independence and inexpensive culture requirements, offer a particularly attractive platform for the application of biotransformation (58). In this context, biotransformation of cinnamyl alcohol to rosavins in hairy roots of Rhodiola kirilowii produced $80-95 \%$ of the glycosides released to the culture media (61). Importantly, biotransformation can drive the discovery of novel plant NPs. For example, a novel terpenoid indole alkaloid in suspension cultures of $C$. roseus was identified by biotransformation of catharantine. The new metabolite was identified as 3-hydroxy-4-imino-catharanthine (62). Therefore, biotransformation constitutes an important alternative to the semi-synthesis strategy by enabling improved stereospecific characteristics, bioavailabilty and the potential to lower the toxicity of the desired NPs.

\section{CAMBIAL MERISTEMATIC CELLS}

An exciting recent technological development in PCC is the isolation, culture and application of CMCs for high-value NP production (46). CMCs are isolated from procambium meristematic cells, which are responsible for the production of $x y-$ lem and phloem within the vasculature (63). CMCs are undifferentiated cells that grow indefinitely and function as plant stem cells $(12,46)$. Isolation of CMCs from $T$. cuspidata, Gingseng panax and Solanum lycopersicum has been reported (46). Recently, the isolation of CMCs from Catharanthus roseus for the production of vindoline, catharanthine and ajmalicine has also been described $(64,65)$.

An important factor that negatively impacts cell culture per- formance is the heterogeneous nature of cultured cells. Typically, contemporary cell cultures are comprised of dedifferentiated cells (DDCs). These cells consist of a mixture of different cell types resulting in a high level of heterogeneity, which significantly contributes to the variability routinely associated with suspension cultures (66). As CMCs are innately undifferentiated plant stem cells, CMCs bypass the negative effects associated with the differentiation step, offering stability in product accumulation for longer periods (46).

Biomass production is another important factor required to achieve high levels of NP synthesis. T. cuspidata CMCs showed superior growth compared to needle or embryo-derived T. cuspidata DDCs when using a solid growth media format over 22 months of culture. Further, when CMCs were placed on liquid media they exhibited reduced aggregation. This is significant, because cell cluster formation can inhibit oxygen and nutrient distribution decreasing NP yield (46).

The reduced aggregation size of CMCs (2-3 cell clusters) also decreases shear sensitivity. Shear stress is a crucial limitation in the scale-up of plant cells, affecting cells by causing ether lysis or death due to fluid motion (67). When cultured in a $10 \mathrm{~L}$ stirred tank bioreactor $T$. cuspidata CMCs grew considerably faster in comparison with DDCs, which rapidly turned necrotic (46). In addition, to aggregation size, the abundant vacuoles and thin cell wall characteristic of CMCs are also thought to increase tolerance to shear stress.

CMCs are also highly responsive to elicitation. For example, the addition of MeJA, a plant immune activator, increased the production of paclitaxel in T. cuspidata CMCs by $14,000 \%$ relative to the production of paclitaxel in needles or embryo-derived DDCs of $220 \%$ and $430 \%$, respectively (46). In C. roseus CMCs, the addition of MeJA, $\beta$-cyclodextrin ( $\beta-C D)$ or a combination of both elicitors, increased the production of ajmalicine by 15,32 and $108 \%$ respectively, relative to non-treated cells (64). Unfortunately, in this case, no direct comparison was made to elicitation in DDCs.

Direct secretion of produced NPs into the media facilitates simpler and less expensive downstream processing, especially important for the industrial scale production of NPs. The capacity of CMCs to release the target NP into the media was assessed during airlift perfusion culture in a $3 \mathrm{~L}$ bioreactor. This style of bioreactor is frequently used for NP production as it can improve both the purification and biosynthesis of the given NP (54). After 45 days of perfusion culture $74 \%$ of paclitaxel from $T$. cuspidata CMCs was release into the medium producing a total of $264 \mathrm{mg} / \mathrm{kg}$ of paclitaxel (46). In contrast, $T$. cuspidata DDCs cultured in an identical system were largely necrotic. Perfusion culture of CMCs therefore both promotes paclitaxel biosynthesis and increases the proportion of this NP that is secreted into the medium.

The use of CMCs provides a promising platform for the production of NPs especially complex molecules synthesized via complicated and poorly characterized biochemical pathways. We anticipate that the application of CMCs to produce NPs 
will rapidly increase in future years due to the established manifold advantages of these cells over that of DDCs. The utility of CMCs for industrial scale production has already been established with the production of gingsenosides from $P$. gingseng CMCs for the production of nutritional, cosmetic and medical products (Table 1) (12). Further, numerous other products derived from CMCs of various plant species are now in development.

\section{SCALE-UP STRATEGIES FOR NP PRODUCTION}

Scaling-up plant cell and organ cultures from lab to industrial scale is obviously a critical step that is often rate limiting for commercialization of NP production. The scaling-up from shake flasks to bioreactors is typically not straightforward due to changes in the cell growth environment in terms of hydrodynamic shear forces and rheological properties (68). Fortunately, some of these limitations can be overcome with improved bioreactor design and optimizing key parameters of the culture and system such as low-shear environment, reducing mass transfer for improved oxygen and nutrient availability and adequate mixing $(68,69)$.

Large-scale culturing of plant cells has been conducted in a variety of bioreactors including standard stirred-tank bioreactors (STR), bubble column bioreactors $(\mathrm{BCB})$, air-life bioreactors (ALB) and other more recent bioreactor designs including: wave bioreactors, membrane bioreactors, hollow fiber bioreactors and rotating drum reactors $(27,69,70)$. The most widely exploited bioreactor is STR, which provides relatively easy scale-up, good fluid mixing and oxygen transfer ability and relatively easy compliance with current Good Manufacture Practices (cGMP). However, BDB and ALB bioreactors are less expensive, in some cases can provide an easier route to scale-up and are generally more straightforward to construct.

Bioreactors are distinct in their modes of operation with batch culture systems typically used in large-scale PCC. However, standard batch processes are often not cost-effective as repeated sterilization, filling and cleaning of the system are required. These factors drove the development of more advanced culture systems such as: fed-back, two-stage, perfusion, semi-continuous and continuous cultures. The choice of the type of culture largely depends on the nature and characteristics of the NP to be synthesized and the specific growth rate, aggregation properties and stress sensitivity, among others, of the plant cells or organ culture to be cultured (69). Perfusion culture, in which fresh medium is continually fed and waste cell-free medium is constantly removed, often provides an optimal approach. The removal of spent media favors productivity and helps eliminate the possibility of inhibition caused by the accumulation of inhibitory metabolites in the medium. However, perfusion bioreactors typically run on a smaller scale in comparison with batch cultures. Although, because plant cells can be reused, this maximises the turnaround time between batch- es significantly increasing productivity $(69,71)$.

An intriguing relatively recent innovation is the use of disposable bioreactors, which can provide platforms for small and medium scale NP production. The disposable bioreactors are made of FDA-approved biocompatible synthetic polymers including: polyethylene, polystyrene, polytetrafluorethylene, polypropylene, and ethylene acetate. These can be, pre-sterilized and then discarded after harvest, minimizing the cost of clean-up and re-sterilization steps associated with mitigating contamination risks $(69,72)$. Various types of disposable bioreactors are currently in use for PCC including: wave-mixed, slug bubble, plastic-lined, stirred bag orbital shaken or stirred bioreactors. Wave bioreactors perhaps represent the most successful type of disposable bioreactor. These consist of an inflated bag placed on a rocking platform that induces wave action within the liquid medium. This disposable bioreactor system has been employed for a number of different plant cell species including: Vitis vinifera, Malus domestica, Nicotiana tabacum (BY-2) and hairy root cultures: Harpagophytum procumbens, Hyoscyamus muticus and $P$. ginseng (73). Furthermore, wave-mixed bioreactors operating in batch and feed mode are already established for the production of NPs for cosmetic products (69).

\section{CONCLUSIONS}

Plants have evolved the capacity to synthesise a vast array of complex chemicals. These natural products have long found a plethora of applications as medicines, dyes, fragrances and flavours. Interest in natural products is now ramping up again, however, due in part to many regulatory agencies increasingly not permitting the addition of synthetic colourants or flavours in food, following studies indicating the possible toxicity of some of these molecules (74). There has also been a recent shift in consumer demand for natural molecules. This has been driven in part by the growing appreciation of the potential health benefits associated with the consumption of NPs. Also, within the pharmaceutical industry, drug screens using NP collections are increasingly being deployed, as libraries of molecules synthesized by combinatorial chemistry beginning to fall out of favour. Collectively, an increasing interest in developing improved strategies for the production of NPs has therefore evolved.

Chief among the platform technologies for NP biosynthesis is PCC. However, the utility of classic DDCs has significant limitations including: a relatively slow growth rate, instability of product yield, sensitivity to shear stress and generation of low concentrations of the given NP. Further, biosynthesis of the target chemical might be localised to other organs rather than roots, precluding the employment of hairy root cultures. Nevertheless, recent developments in cell the selection of high performing cell lines, biotransformation, cell permeabilisation and culture optimisation, among others is beginning to increase the utility of DCCs and hairy root cultures (Fig. 1). 


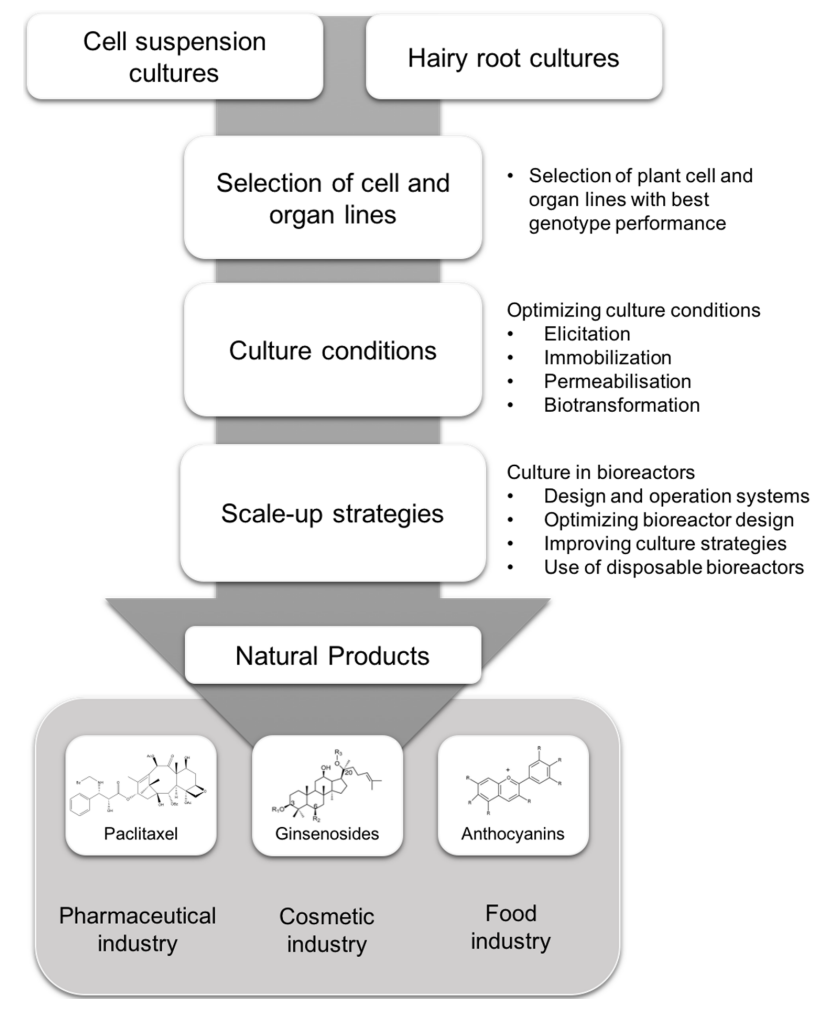

Fig. 1. Strategies for the production of natural products from either plant cell suspensions or hairy root culture for the pharmaceutical, cosmetic or food industries.

When applied in combination these advances are particularly powerful. For example, in situ product removal, in tandem with elicitation and immobilization increased the production of ajmalicine in C. roseus cell suspension from $2 \mathrm{mg} / \mathrm{L}$ to 90 $\mathrm{mg} / \mathrm{L}$ (75). Superimposed upon these is the recent isolation, culture and deployment of CMCs. These innately undifferentiated cells, plant stem cells, circumvent many of the current limitations associated with the application of DDCs and hairy root cultures. Thus, the use of CMCs with rather than DDCs, in combination with the new advances in associated PCC technologies, such as biotransformation or cell permeabilisation, will provide significant opportunities for the production of NPs in plants. Especially, when aligned with the recent developments in scale-up capability and bioreactor design. Therefore, there are exciting times ahead for both academic research and commercial development within the area of plant NPs.

\section{ACKNOWLEDGEMENTS}

Work on cambial meristematic cells in the Loake lab is funded by Unhwa Corp. and the BBSRC. M. Ochoa-Villarreal is supported by a scholarship from CONACYT, Mexico and S. Howat by a BBSRC-CASE award.

\section{REFERENCES}

1. Fiehn $\mathrm{O}$ (2002) Metabolomics--the link between genotypes and phenotypes. Plant Mol Biol 48, 155-171

2. Newman DJ, Cragg GM (2012) Natural products as sources of new drugs over the 30 years from 1981 to 2010. J Nat Prod 75, 311-335

3. Ambati RR, Phang SM, Ravi S, Aswathanarayana RG (2014) Astaxanthin: sources, extraction, stability, biological activities and its commercial applications a review. Mar Drugs 12, 128-152

4. Delgado-Vargas F, Jiménez AR, Paredes-López O (2000) Natural pigments: carotenoids, anthocyanins, and betalains characteristics, biosynthesis, processing, and stability. Crit Rev Food Sci Nutr 40, 173-289

5. Miresmailli S, Isman MB (2014) Botanical insecticides inspired by plant-herbivore chemical interactions. Trends Plant Sci 19, 29-35

6. Copping LG (1998) Book Review: The neem tree: source of unique natural products for integrated pest management, medicine, industry and other purposes. Pestic Sci 52, 305-306

7. Javed S (2014) Aloe Vera Gel in Food, Health Products, and Cosmetics Industry. Stud Nat Prod Chem 261-285

8. Cavanagh HM, Wilkinson JM (2002) Biological Activities of Lavender Essential Oil. Phytother Res 308, 301-308

9. Wu S, Chappell J (2008) Metabolic engineering of natural products in plants; tools of the trade and challenges for the future. Curr Opin Biotechnol 19, 145-152

10. Howat S, Park B, Oh IS, Jin YW, Lee EK, Loake GJ (2014) Paclitaxel: biosynthesis, production and future prospects. N Biotechnol 31, 242-245

11. Fischer R, Vasilev N, Twyman RM, Schillberg S (2015) High-value products from plants: the challenges of process optimization. Curr Opin Biotechnol 32, 156-162

12. Ochoa-Villarreal M, Howat S, Jang $M O$ et al (2015) Cambial meristematic cells: a platform for the production of plant natural products. N Biotechnol 32, 581-587

13. Roberts SC (2007) Production and engineering of terpenoids in plant cell culture. Nat Chem Biol 3, 387-395

14. Nosov AM (2012) Application of cell technologies for production of plant-derived bioactive substances of plant origin. Appl Biochem Microbiol 48, 609-624

15. Wilson SA, Roberts SC (2012) Recent advances towards development and commercialization of plant cell culture processes for the synthesis of biomolecules. Plant Biotechnol J 10, 249-268

16. Murthy HN, Georgiev MI, Park SY, Dandin VS, Paek KY (2015) The safety assessment of food ingredients derived from plant cell, tissue and organ cultures: a review. Food Chem 176, 426-432

17. Chen W, Viljoen AM (2010) Geraniol - A review of a commercially important fragrance material. South African J Bot 76, 643-651

18. Vasilev N, Schmitz C, Dong L et al (2014) Comparison of plant-based expression platforms for the heterologous production of geraniol. Plant Cell Tissue Organ Cult 117, 373-380

19. Verpoorte R, Contin A, Memelink J (2002) Biotechnology for the production of plant secondary metabolites. Phyto- 
chem Rev 1, 13-25

20. Guillon S, Trémouillaux-Guiller J, Pati PK, Rideau M, Gantet P (2006) Hairy root research: recent scenario and exciting prospects. Curr Opin Plant Biol 9, 341-346

21. Shanks JV, Morgan J (1999) Plant "hairy root" culture. Biochem Eng J 10, 151-155

22. Wink M, Alfermann AW, Franke R et al (2005) Sustainable bioproduction of phytochemicals by plant in vitro cultures: anticancer agents. Plant Genet Resour Charact Util 3, 90-100

23. Srivastava S, Srivastava AK (2007) Hairy Root Culture for Mass-Production of High-Value Secondary Metabolites. Crit Rev Biotechnol 27, 29-43

24. Murthy HN, Lee EJ, Paek KY (2014) Production of secondary metabolites from cell and organ cultures: strategies and approaches for biomass improvement and metabolite accumulation. Plant Cell Tissue Organ Cult 118, 1-16

25. Georgiev M, Pavlov A, Ilieva M (2006) Selection of high rosmarinic acid producing Lavandula vera MM cell lines. Process Biochem 41, 2068-2071

26. Dhawan S, Shasany AK, Naqvi AA, Kumar S, Suman PS (2003) Menthol tolerant clones of Mentha arvensis: approach for in vitro selection of menthol rich genotypes. Plant Cell Tissue Organ Cult 75, 87-94

27. Georgiev M, Weber J, Maciuk A (2009) Bioprocessing of plant cell cultures for mass production of targeted compounds. Appl Microbiol Biotechnol 83, 809-823

28. Mittelsten Scheid O, Jakovleva L, Afsar K, Maluszynska J, Paszkowski J (1996) A change of ploidy can modify epigenetic silencing. Proc Natl Acad Sci U S A 93, 71147119

29. Baebler $\check{S}$, Hren M, Camloh M et al (2005) Establishment of cell suspension cultures of yew (Taxus $\times$ media Rehd. and assessment of their genomic stability. Vitr Cell Dev Biol Plant 41, 338-343

30. Raven N, Rasche S, Kuehn C et al (2015) Scaled-up manufacturing of recombinant antibodies produced by plant cells in a 200-L orbitally-shaken disposable bioreactor. Biotechnol Bioeng 112, 308-321

31. Murashige T, Skoog F (1962) A Revised Medium for Rapid Growth and Bio Assays with Tobacco Tissue Cultures. Physiol Plant 15, 473-497

32. Schenk RU, Hildebrandt AC (1972) Medium and techniques for induction and growth of monocotyledonous and dicotyledonous plant cell cultures. Can J Bot 50, 199-204

33. Gamborg OL, Miller RA, Ojima K (1968) Nutrient requirements of suspension cultures of soybean root cells. Exp Cell Res 50, 151-158

34. Linsmaier EM, Skoog F (1965) Organic Growth Factor Requirements of Tobacco Tissue Cultures. Physiol Plant $18,100-127$

35. Bhojwani SS, Dantu PK (2013) Production of industrial phytochemicals. In: Plant Tissue Culture: An Introductory Text p275-286

36. Holland T, Blessing D, Hellwig S, Sack M (2013) The in-line measurement of plant cell biomass using radio frequency impedance spectroscopy as a component of process analytical technology. Biotechnol J 8, 1231-1240

37. Vasilev N, Grömping U, Lipperts A, Raven N, Fischer R, Schillberg S (2013) Optimization of BY-2 cell suspension culture medium for the production of a human antibody using a combination of fractional factorial designs and the response surface method. Plant Biotechnol J 11, 867-874

38. Häkkinen ST, Raven N, Henquet M et al (2014) Molecular farming in tobacco hairy roots by triggering the secretion of a pharmaceutical antibody. Biotechnol Bioeng 111, 336-346

39. Vasilev N, Schmitz C, Grömping U, Fischer R, Schillberg S (2014) Assessment of Cultivation Factors that Affect Biomass and Geraniol Production in Transgenic Tobacco Cell Suspension Cultures. PLoS One 9, e104620

40. Pauwels L, Inzé D, Goossens A (2009) Jasmonate-inducible gene: What does it mean? Trends Plant Sci 14, 87-91

41. Roberts SC, Naill M, Gibson DM, Shuler ML (2003) A simple method for enhancing paclitaxel release from Taxus canadensis cell suspension cultures utilizing cell wall digesting enzymes. Plant Cell Rep 21, 1217-1220

42. Zhao J, Zhu WH, Hu Q (2001) Selection of fungal elicitors to increase indole alkaloid accumulation in Catharanthus roseus suspension cell culture. Enzyme Microb Technol 28, 666-672

43. Gundlach H, Müller MJ, Kutchan TM, Zenk MH (1992) Jasmonic acid is a signal transducer in elicitor-induced plant cell cultures. Proc Natl Acad Sci U S A 89, 23892393

44. Ketchum RE, Gibson DM, Croteau RB, Shuler ML (1999) The kinetics of taxoid accumulation in cell suspension cultures of Taxus following elicitation with methyl jasmonate. Biotechnol Bioeng 62, 97-105

45. Luo J, He GY (2004) Optimization of elicitors and precursors for paclitaxel production in cell suspension culture of Taxus chinensis in the presence of nutrient feeding. Process Biochem 39, 1073-1079

46. Lee EK, Jin YW, Park JH et al (2010) Cultured cambial meristematic cells as a source of plant natural products. Nat Biotechnol 28, 1213-1217

47. Lijavetzky D, Almagro L, Belchi-Navarro S, MartínezZapater JM, Bru R, Pedreño MA (2008) Synergistic effect of methyljasmonate and cyclodextrin on stilbene biosynthesis pathway gene expression and resveratrol production in Monastrell grapevine cell cultures. BMC Res Notes 1, 132

48. Sabater-Jara AB, Onrubia M, Moyano E et al (2014) Synergistic effect of cyclodextrins and methyl jasmonate on taxane production in Taxus $x$ media cell cultures. Plant Biotechnol J 12, 1075-1084

49. Brena B , González-Pombo P Batista-Viera F (2013) Immobilization of enzymes: a literature survey. Immobil Enzym Cells 1051, 15-31

50. Bentebibel S, Moyano E, Palazón J et al (2005) Effects of immobilization by entrapment in alginate and scale-up on paclitaxel and baccatin III production in cell suspension cultures of Taxus baccata. Biotechnol Bioeng 89, 647-655

51. Rao SR, Ravishankar GA (2002) Plant cell cultures: Chemical factories of secondary metabolites. Biotechnol Adv 20, 101-153

52. Bodeutsch T, James E, Lee J (2001) The effect of immobilization on recombinant protein production in plant cell culture. Plant Cell Rep 20, 562-566 
53. Brodelius P, Nilsson K (1983) Permeabilization of immobilized plant cells, resulting in release of intracellularly stored products with preserved cell viability. Eur J Appl Microbiol Biotechnol 17, 275-280

54. Wang C, Wu J, Mei X (2001) Enhanced Taxol Production and Release in Taxus chinensis Cell Suspension Cultures with Selected Organic Solvents and Sucrose Feeding. Biotechnol Prog 17, 89-94

55. Freeman A, Woodley JM, Lilly MD (1993) In situ product removal as a tool for bioprocessing. Nat Biotech 11, 1007-1012

56. Malik S, Hossein Mirjalili M, Fett-Neto AG, Mazzafera $P$, Bonfill M (2013) Living between two worlds: two-phase culture systems for producing plant secondary metabolites. Crit Rev Biotechnol 33, 1-22

57. Talano MA, Oller AL, González PS, Agostini E (2012) Hairy Roots, their Multiple Applications and Recent Patents. Recent Pat Biotechnol 6, 115-133

58. Banerjee S, Singh S, Rahman LU (2012) Biotransformation studies using hairy root cultures - A review. Biotechnol Adv 30, 461-468

59. Giri A, Dhingra V, Giri CC, Singh A, Ward OP, Narasu MLL (2001) Biotransformations using plant cells, organ cultures and enzyme systems: current trends and future prospects. Biotechnol Adv 19, 175-199

60. Ishihara K, Hamada H, Hirata T, Nakajima N (2003) Biotransformation using plant cultured cells. J Mol Catal B Enzym 23, 145-170

61. Grech-Baran M, Sykłowska-Baranek K, Krajewska-Patan A, Wyrwał A, Pietrosiuk A (2014) Biotransformation of cinnamyl alcohol to rosavins by non-transformed wild type and hairy root cultures of Rhodiola kirilowii. Biotechnol Lett 36, 649-656

62. He S, Zhu J, Zi J, Zhou P, Liang J, Yu R (2015) A novel terpenoid indole alkaloid derived from catharanthine via biotransformation by suspension-cultured cells of Catharanthus roseus. Biotechnol Lett 37, 2481-2487

63. Ye ZH (2002) Vascular tissue differentiation and pattern formation in plants. Annu Rev Plant Biol 53, 183-202
64. Zhou P, Yang J, Zhu J et al (2015) Effects of $\beta$-cyclodextrin and methyl jasmonate on the production of vindoline, catharanthine, and ajmalicine in Catharanthus roseus cambial meristematic cell cultures. Appl Microbiol Biotechnol 2015, 7035-7045

65. Moon SH, Venkatesh J, Yu JW, Park SW (2015) Differential induction of meristematic stem cells of Catharanthus roseus and their characterization. C R Biol 338, 745-756

66. Roberts S, Kolewe M (2010) Plant natural products from cultured multipotent cells. Nat biotechnol 28, 1175-1176

67. Joshi JB, Elias CB, Patole MS (1996) Role of hydrodynamic shear in the cultivation of animal, plant and microbial cells. Chem Eng J Biochem Eng J 62, 121-141

68. Sajc L, Grubisic D, Vunjak-Novakovic G (2000) Bioreactors for plant engineering: an outlook for further research. Biochem Eng J 4, 89-99

69. Georgiev MI, Eibl R, Zhong JJ (2013) Hosting the plant cells in vitro: recent trends in bioreactors. Appl Microbiol Biotechnol 97, 3787-3800

70. Huang TK, McDonald KA (2012) Bioreactor systems for in vitro production of foreign proteins using plant cell cultures. Biotechnol Adv 30, 398-409

71. Xu J, Ge X, Dolan MC (2011) Towards high-yield production of pharmaceutical proteins with plant cell suspension cultures. Biotechnol Adv Elsevier Inc 29, 278-299

72. Eibl R, Kaiser S, Lombriser R, Eibl D (2010) Disposable bioreactors: The current state-of-the-art and recommended applications in biotechnology. Appl Microbiol Biotechnol 86, 41-49

73. Eibl R, Werner S, Eibl D (2009) Disposable bioreactors for plant liquid cultures at litre-scale. Eng Life Sci 9, 156-164

74. Sowbhagya HB, Chitra VN (2010) Enzyme-assisted extraction of flavorings and colorants from plant materials. Crit Rev Food Sci Nutr 50, 146-161

75. Asada M, Shuler ML (1989) Stimulation of ajmalicine production and excretion from Catharanthus roseus: effects of adsorption in situ, elicitors and alginate immobilization. Appl Microbiol Biotechnol 30, 475-481 